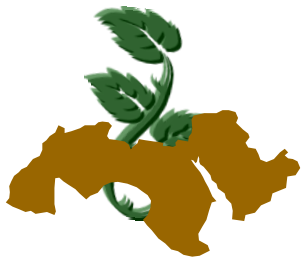

Arab Univ.

J. Agric. Sci., Ain Shams Univ., Cairo, 23(1), 13 - 23, 2015

\title{
EFFECT OF USING BIO - AND ORGANIC FERTILIZERS ON PRODUCTIVITY AND QUALITY OF CUCUMBER CROP UNDER PLASTIC HOUSES
}

\author{
Al-Hmoudi ${ }^{1}$, A.S.; M.H. Mohamed ${ }^{2}$; S.M. Al-Menaway² \\ and S.A. Hussain \\ 1- Ministry of Environment and Water United Arab Emirates \\ 2- Hort, Dept. Fac. of Agric, Ain Shams Univ., Cairo, Egypt
}

Keywords: Organic, Fertilizers, Bio-organic Cucumber, Plastic House. Productivity

\section{ABSTRACT}

An experiment was carried out to study the effect of Bio and organic fertilizer on cucumber growth and yield during two successive seasons of 2010 and 2011 at Northern region in united Arab Emirates. The Queen cucumber hybrid was fertilized with different organic fertilizers i.e. Horse manure, compost, chickens manure and cows manure. Also using the bio fertilizer i.e. phosphobactein, Azotobacter and mycorrhizal. The results showed that cucumber yields differed in their response to the bio and organic fertilizer.

The results showed that the compost was higher nitrogen percent and lower in $\mathrm{C} / \mathrm{N}$ ratio, and $\mathrm{pH}$, than the others organic fertilizer especially horse manure. The study demonstrated that the average cumulative cucumber yield was higher with compost $+22(\mathrm{gm})$ mycorhizol/ plots treatments compared to other treatments throughout the experiment during the two successive winter seasons of 2010 and 2011. The plant height and plant fresh weight $(\mathrm{g})$, with $\mathrm{N} 100 \%$ mineral (control) deceased by $28 \%$ and $40 \%$ compared to $\mathrm{N}$ $100 \%$ organic (Compost) respectively during the winter season of 2010. The nitrogen, phosphorus and potassium content of cucumber fruits (\%) significantly increased, as did the soil with the increase of organic fertilizes applied. The experimental results confirmed the combination of bioand organic fertlizers could increase plant growth, yield and quality. It also confirmed that composted organic fertlizers can be used a source of nutration instead of chemical fertlizers for cucumber plants.

\section{INTRODUCTION}

It is very important depended on natural crops. we should be de creased the chemical fertilizers, but need to be use Bio- \& organic fertilizers. Protected cultivation is now representing a significant contributes and expanding markedly in the newly reclaimed lands especially in united Arab Emirates. Cmjucumber is one of the most important vegetablegrown under plastic houses and produce high total yields.

Also it's a good source of vitamins, minerals, fibers. Cucumber flesh is rich in potassium and vitamin C.

Cucumber contains calcium $(20 \mathrm{gm} / 100 \mathrm{~g})$, iron $(0.7 \mathrm{mg} / 100 \mathrm{~g})$, thiamin $(0.3 \mathrm{mg} / 100 \mathrm{~g})$, niacin $(0.2$ $\mathrm{mg} / 100 \mathrm{~g})$ and riboflavin $(0.01 \mathrm{mg} / 100 \mathrm{~g})$.

In this studies includes two different resources for the fertilizers, bio-and organic fertilizers. Hekal, A.I.A. (2001). Reported that the fungicides and pesticides increased the product costs and same time decreased the profit, cucumber was found in subtropical and tropical region favorable environmental condition for humid topics.

Regab (1984) find that the average fruit weight was controlled by 2-3 genes and this number of genes was highly affected by environmental conditions.

In soil Masloand Gamaynnov (1989) reported that the organic manure 40 ton/hectar for cucumber increased total yield $57: 136 \%$. 
Eissa (1996) observed from his studies on the application organic manure increased significantly the fresh weight, also increased phosphorus in cucumber fruits while nitrogen content in cucumber shoot was increased. Vogtman et al (1993) reported that, compost treatments resulted in lower vegetable yields in the first two years but there were no different after the third year. Kostov et al (1995) reported that it was more economical to use composting vegetable residues for greenhouse cucumber production than cattle manure. They also reported that greenhouse cucumbers (curcumas sativus L.) grown on a medium containing composted vegetables or vegetable waste with the addition of synthetic nutrients produced fruit 10 to 20 days earlier and had a yield 48 to $79 \%$ higher than those grown in soil mixed with cattle manure at a 2.1 ratio (dry weight basis).

Roe et al (1997) studied cucumbers in a sandy soil fertilized with compost or mineral fertilizers. They found that, yields were usually higher when compost was combined with mineral fertilizers.

Esawy et al (2009) reported that the average nitrate content of cucumber fruits was only detected in the plots treated with $100 \%$ organic $\mathrm{N}$ from the composted tested.

The objectives of this study were to assess the effect of four types from organic fertilizers (Horse manure, compost, chickens manure and cows manure) and three bio-organic fertilizers (phosphobacterin), Azatobacterand mycorrhizal), on cucumber (cucumis sativa) plants during the two seasons 2010/2011 and sandy soil properties.

\section{MATERIALS AND METHODS}

An experiment was carried out in an un heated plastic house at the ministry of water and Environmental, experimental farm, Northern region in UAE during winter seasons of 2010 and 2011. The hybrids Queen F1 were used. This hybrid are already grown as minicucumbers on very large scales by most of the growers in the UAE. Cucumbers were seeded in cell flats (cell size $3 \times 3 \times 10 \mathrm{~cm}$ ) filled with peat: perlite mixture, placed on benches under the plastic house conditions, for a period of 6 weeks. Seedlings were then transplanted (November $8^{\text {th }}$ 2010 and November $15^{\text {th }} 2011$ ) to soil and grown under controlled conditions in an experimental plastichaue.

The physical and chemical characteristic of the experimental soil sites are presented in Table (1). A split plot design with three replicates was used and the area of each replicate plot was $4.8 \mathrm{~m}^{2}$. The organic fertilizers were arranged in main pols, while the boi-organic fertilizer, plotted at random in sub plats.

Table 1. The physical and chemical analysis of the experimental soil in 2010 and 2011

\begin{tabular}{|ccc|}
\hline Soil properties & $\begin{array}{c}\mathbf{2 0 1 0} \\
\text { seasons }\end{array}$ & $\begin{array}{c}\mathbf{2 0 1 1} \\
\text { seasons }\end{array}$ \\
\hline A-Physical analysis & & \\
Coarse sand \% & 8.6 & 8.7 \\
Fin Sand \% & 63.8 & 64.1 \\
Silt \% & 12.8 & 12.9 \\
Clay \% & & \\
Soil type & Sandy loam & Sandy loam \\
B-Chemical analysis & & \\
pH (1 : 5) & 8.2 & 8.5 \\
EC (mmbos/cm at & 8.11 & 8.61 \\
250) & & \\
Total N (ppm) & 135.2 & 159.1 \\
Available P (ppm) & 6.5 & 6.9 \\
Available K (ppm) & 69.2 & 80.3 \\
Iron & 3.8 & 4.0 \\
Zinc & 0.7 & 0.91 \\
Manganese & 2.9 & 3.2 \\
Copper & 0.22 & 0.31 \\
\hline
\end{tabular}

Plants were spaced at $50 \mathrm{~cm}$ a part in 5 rows plastic house in rows of $40 \mathrm{~m}$ long. $50 \mathrm{~cm}$ deep and $50 \mathrm{~cm}$ wide. The soil was sandy is texture and drip irrigation system was used.

Four different organic fertilizers were applied + three bio-organic fertilizer were applied.

1- Control full dose chemical $100 \%$ NPK.

2- $100 \%$ dose NPK organic (Compost) + Phosphobacterin.

3- $100 \%$ dose NPK organic (Compost) + Azotobacter.

4- $100 \%$ dose NPK organic (Compos+) + Mycorrhizal.

5- $100 \%$ dose NPK Horse manure+ Phosphobacterin.

6- $100 \%$ dose NPK Horse manure + Azotobacter.

7- $100 \%$ dose NPK Horse manure + Mycorrhizal.

8- $100 \%$ dose NPK chickens manure + Phosphobacterin.

9- $100 \%$ dose NPK chickens manure + Azotobacter.

$10-100 \%$ dose NPK chickens manure + My corrhizal..

$11-100 \%$ dose NPK cowesmanure + Phosphobacterin.

$12-100 \%$ dose NPK Cowesmanure + Azotobacter. $13-100 \%$ dose NPK Cowes manure + My corrhizal. 

Under Plastic Houses

Table 2. The chemical analysis of the experimental organic fertilizers

\begin{tabular}{|ccccccccc|}
\hline Sampel & N & P2O5 & pH & EC & M.C.\% & O.M.\% & NaCl\% & C/N ratio \\
\hline Horse Manure & 1.4 & 1.14 & 6.35 & 4.80 & 24.50 & 80.58 & 1.18 & 33.46 \\
Compost & 3.39 & 1.95 & 5.84 & 12.77 & 5.78 & 72.37 & 1.09 & 12.41 \\
Chickens manure & 2.77 & 3.00 & 7.02 & 19.11 & 35.03 & 79.57 & 2.56 & 16.70 \\
Cows manure & 1.51 & 1.88 & 8.05 & 14.26 & 9.27 & 46.34 & 2.18 & 17.84 \\
\hline
\end{tabular}

Other cultural practices such as, irrigation, pesticide were applied according to the recommendation of ministry of water \& Environmental. Plant height and Fresh weight of plants were estimated at the end of the harvesting season. Number of fruits/plant, average fruit weight (gm) and, total yield per plant $(\mathrm{Kg})$ were calculated at the acceptable marketing stage.

Nitrogen, phosphorous and potassium content in cucumber fruits were analyzed according to the methods described by (Miller and Keeny, 1982), (Arnold et al 1992) and (Naseem, 2003) respectively.

\section{RESULTS AND DISCUSSION}

\section{Vegetative growth}

\section{Plant height}

Fertilization had a significant effect on the plant height of cucumber plants during the two successive winter seasons of (2010 and 2011). (Table 3). Comparing treatments with $100 \%$ organic fertilizers and bio-organic fertilizers, the highest plant height of cucumber were in the plants treated with the compost compared with the rest of organic fertilizer and control (Table 2). No significant differences were found between chicken and cows manure treatments since bio-organics applied at the harvest stages. In addition control did not reflect any negative effect on plant height at two sucussive seasons.

Mycorrhizal treatments and compost adversely affected plant height with highly significant results compared with phosphobacterin and Azotobacter treatments.

However, using bio-organics treatments had a positive effects on plant height compared with control.

Plants grown with compost +mycorrhizal treatments were superior in plant height compared with any other treatments included in the experiment and control (Table 3).
This treatment gave 69.2 and $70.5 \mathrm{~cm}$ compared with control $53.7 \% 50.3 \mathrm{~cm}$ increment in plant height over seasons 2010 and 2011 respectively. This means that compost + mycorrhizal fertilizers are quite favorable for the plant height on cucumber plants growing in winter seasons.

These results agreed with those obtained by Abdel-Maniem et al (2002) and Abou-Hadid et al (2003).

\section{Plant fresh weight $(\mathrm{Kg})$}

Bio-and organic fertilization had a significant effect on the average plant fresh weight of cucumber plants for the two successive winter seasons of 2010 and 2011 (Table 4).

Plant fresh weight treated with $100 \%$ compost + mycorrhizal gave the highest results than in the other treatments of organic fertilization especially in the plote treated with chemical fertilizers only (control). The vules were $2.06 \& 2.10 \mathrm{~kg} / \mathrm{plant}$ in two successive seasons respectively. This might be due to the availability of water and nitrogen provided by compost to the root system of the plants. These results were in accordance with those Abou-Hadid et al (1993) and Frank, J. (1976).

\section{Number of fruits/plant}

Interaction between the compost and microbial is the key objective to solve the conflict between high yields and environmental protection. The fruits number / plant in the $100 \%$ compost +22 gramemycorhizal in cucumber plot treatment were higher than in the other treatments throughout the experiment (Table 5).

Role of organics in increasing number of fruits/ plant of cucumber was attributed to supply of all essential nutrients due to continus mineralization of organic manures. Our results also showed that the cucumber responded more to compost than the other organic manure + bio-organics has been treated in our experiments. 
Table 3. Effect of using bio- and organic fertilizers on plant height $(\mathrm{cm})$ of Queen cucumber cv (Cucumus saliva.) during seasons 2010 and 2011

\begin{tabular}{|ccccc|}
\hline \multirow{2}{*}{ Treatments } & \multicolumn{3}{c}{ First season } & \multirow{2}{*}{ Mean } \\
\cline { 2 - 4 } & Phos. & Aoz. & Mr. & \\
\hline Horse manure & $55.8 \mathrm{e}-\mathrm{f}$ & $56.1 \mathrm{ef}$ & $58.2 \mathrm{de}$ & $56.70 \mathrm{C}$ \\
Compost & $65.4 \mathrm{ab}$ & $66.0 \mathrm{ab}$ & $69.2 \mathrm{a}$ & $66.99 \mathrm{~A}$ \\
Chickens manure & $64.4 \mathrm{be}$ & $63.2 \mathrm{be}$ & $62.5 \mathrm{be}$ & $63.39 \mathrm{~B}$ \\
Cows manure & $62.7 \mathrm{be}$ & $60.5 \mathrm{~cd}$ & $63.3 \mathrm{be}$ & $62.20 \mathrm{~B}$ \\
\hline Control & $51.9 \mathrm{gh}$ & $50.4 \mathrm{~h}$ & $53.7 \mathrm{f}-\mathrm{g}$ & $52.00 \mathrm{D}$ \\
\hline Mean & $60.1 \mathrm{AB}$ & $59.26 \mathrm{~B}$ & $61.41 \mathrm{~A}$ & \\
\hline & & Second season & & \\
\hline Horse manure & $60.30 \mathrm{a}-\mathrm{c}$ & $58.40 \mathrm{~b}-\mathrm{d}$ & $63.20 \mathrm{ab}$ & $60.63 \mathrm{AB}$ \\
Compost & $66.50 \mathrm{ab}$ & $63.00 \mathrm{ab}$ & $70.50 \mathrm{a}$ & $66.67 \mathrm{~A}$ \\
Chickens manure & $57.40 \mathrm{~b}-\mathrm{d}$ & $55.70 \mathrm{~b}-\mathrm{d}$ & $62.40 \mathrm{ab}$ & $58.50 \mathrm{~B}$ \\
Cows manure & $61.20 \mathrm{a}-\mathrm{c}$ & $60.20 \mathrm{a}-\mathrm{c}$ & $65.00 \mathrm{ab}$ & $62.13 \mathrm{AB}$ \\
\hline Control & $47.30 \mathrm{~d}$ & $48.50 \mathrm{~d}$ & $50.30 \mathrm{~cd}$ & $48.70 \mathrm{C}$ \\
\hline Mean & $58.54 \mathrm{AB}$ & $57.16 \mathrm{~B}$ & $62.28 \mathrm{~A}$ & \\
\hline
\end{tabular}

Means having the same letter (S) are not significant at $5 \%$ level (Phos) phosphobacterin \& (Aoz) Azotobacter \& (Mr.) mycorrhizal.

Table 4. Effect of using bio- and organic fertilization on plant fresh weight (Kg) of Queen cucumber cv (Cucumus sativa.) during seasons 2010 and 2011

\begin{tabular}{|ccccc|}
\hline \multirow{2}{*}{ Treatments } & \multicolumn{3}{c}{ First season } & \multirow{2}{*}{ Mean } \\
\cline { 2 - 4 } & Phos. & Aoz. & Mr. & \\
\hline Horse manure & $1.67 \mathrm{ef}$ & $1.67 \mathrm{ef}$ & $1.77 \mathrm{~d}-\mathrm{f}$ & $1.70 \mathrm{C}$ \\
Compost & $2.08 \mathrm{ab}$ & $1.92 \mathrm{c}-\mathrm{d}$ & $2.18 \mathrm{a}$ & $2.06 \mathrm{~A}$ \\
Chickens manure & $1.85 \mathrm{c}-\mathrm{e}$ & $1.63 \mathrm{f}$ & $1.92 \mathrm{~b}-\mathrm{d}$ & $1.80 \mathrm{C}$ \\
Cows manure & $1.93 \mathrm{~b}-\mathrm{d}$ & $1.86 \mathrm{c}-\mathrm{e}$ & $2.02 \mathrm{a}-\mathrm{c}$ & $1.93 \mathrm{~B}$ \\
\hline Control & $1.21 \mathrm{~g}$ & $1.17 \mathrm{~g}$ & $1.30 \mathrm{~g}$ & $1.23 \mathrm{D}$ \\
\hline Mean & $1.75 \mathrm{~B}$ & $1.65 \mathrm{C}$ & $1.84 \mathrm{~A}$ & \\
\hline & & Second season & & \\
\hline Horse manure & $1.53 \mathrm{~d}-\mathrm{f}$ & $1.74 \mathrm{~cd}$ & $1.62 \mathrm{de}$ & $1.63 \mathrm{~B}$ \\
Compost & $2.00 \mathrm{a}-\mathrm{C}$ & $2.00 \mathrm{a}-\mathrm{c}$ & $2.30 \mathrm{a}$ & $2.10 \mathrm{~A}$ \\
Chickens manure & $1.77 \mathrm{~cd}$ & $1.53 \mathrm{~d}-\mathrm{f}$ & $1.85 \mathrm{~b}-\mathrm{d}$ & $1.72 \mathrm{~B}$ \\
Cows manure & $2.00 \mathrm{a}-\mathrm{C}$ & $1.76 \mathrm{~cd}$ & $2.17 \mathrm{ab}$ & $1.98 \mathrm{~A}$ \\
\hline Control & $1.11 \mathrm{~kg}$ & $1.31 \mathrm{e}-\mathrm{g}$ & $1.27 \mathrm{fg}$ & $1.23 \mathrm{C}$ \\
\hline Mean & $1.68 \mathrm{~B}$ & $1.67 \mathrm{~B}$ & $1.84 \mathrm{~A}$ & \\
\hline
\end{tabular}

Means having the same letter (S) are not significant at $5 \%$ level (Phos) phosphobacterin \& (Aoz) Azotobacter \& (Mr.) mycorrhizal 

Under Plastic Houses

Table 5. Effect of using bio- and organic fertilizers on number of fruit / plant of Queen cucumber cv (Cucumus sativa.) during seasons 2010 and 2011

\begin{tabular}{|c|c|c|c|c|}
\hline \multirow{2}{*}{ Treatments } & \multicolumn{3}{|c|}{ First season } & \multirow{2}{*}{ Mean } \\
\hline & Phos. & Aoz. & Mr. & \\
\hline Horse manure & 24.74 ef & $21.76 \mathrm{fg}$ & $25.67 \mathrm{de}$ & $24.04 \mathrm{C}$ \\
\hline Compost & $29.71 \mathrm{ab}$ & $28.25 \mathrm{~b}-\mathrm{d}$ & $31.67 \mathrm{a}$ & $29.90 \mathrm{~A}$ \\
\hline Chickens manure & $26.80 \mathrm{~b}-\mathrm{e}$ & $25.46 \mathrm{de}$ & 26.42 b-e & $26.25 \mathrm{~B}$ \\
\hline Cows manure & $26.08 \mathrm{c}-\mathrm{e}$ & $26.50 \mathrm{~b}-\mathrm{e}$ & $29.21 \mathrm{a}-\mathrm{c}$ & $27.22 \mathrm{~B}$ \\
\hline Control & $21.09 \mathrm{~g}$ & $20.88 \mathrm{~g}$ & $20.42 \mathrm{~g}$ & $20.80 \mathrm{D}$ \\
\hline Mean & $25.68 \mathrm{AB}$ & $24.57 \mathrm{~B}$ & $26.67 \mathrm{~A}$ & \\
\hline \multicolumn{5}{|c|}{ Season 2011} \\
\hline Horse manure & $26.33 \mathrm{c}-\mathrm{e}$ & $23.50 \mathrm{e}-\mathrm{g}$ & 24.67 e-f & $24.83 \mathrm{C}$ \\
\hline Compost & $28.67 \mathrm{~b}-\mathrm{d}$ & $27.50 \mathrm{~b}-\mathrm{e}$ & $33.00 \mathrm{a}$ & $29.72 \mathrm{~A}$ \\
\hline Chickens manure & $31.00 \mathrm{ab}$ & $23.50 \mathrm{e}-\mathrm{g}$ & $27.33 \mathrm{~b}-\mathrm{e}$ & $27.28 \mathrm{~B}$ \\
\hline Cows manure & $25.00 \mathrm{~d}-\mathrm{f}$ & $27.33 \mathrm{~b}-\mathrm{e}$ & $30.00 \mathrm{a}-\mathrm{c}$ & $27.44 \mathrm{AB}$ \\
\hline Control & $21.00 \mathrm{fg}$ & $19.67 \mathrm{~g}$ & $19.33 \mathrm{~g}$ & $20.00 \mathrm{D}$ \\
\hline Mean & $26.40 \mathrm{~A}$ & $24.30 \mathrm{~B}$ & $26.87 \mathrm{~A}$ & \\
\hline
\end{tabular}

Means having the same letter (S) are not significant at $5 \%$ level (Phos) phosphobacterin \& (Aoz) Azotobacter \& (Mr.) mycorrhizal.

\section{Average Fruit weight (gm)}

Growing cucumber plant in the compost +22 gramemycrohizal / plote gave significantly greater fruit weight compared to the other organic treatments used in both successive seasons (Table 6).

Similarly, other levels gave significantly higher fruit weight in the control which included the chemical mineral only. This might be due to the availability of water and nitrogen provided to the roots system of the plants by using the bio-and organic fertilization. The best results was on compost + myecorrhizal treatments in the second season than the first season, values were 120.3 and $115(\mathrm{gm})$ respectively.

These results could be explained through the effect of the availability of organic fertilization on average fruit weight (Bradley and Flemig, 1958). Also these results agree with the findings of Shahein and El-Habbasha (1988), which indicated that the average fruit weight significantly differed within different evaluated cucumber hybrids.
The lowest total yield was obtained when cucumber plants were grown in control level (Table 7).

It seems that bio - and organic fertilizers are essential factors for cucumber plants production. The compost +22 (gm) mycorrhizal/plote had positive effect on total yield of cucumber, it gave higher yield than other treatments and control. Using the chemical mineral only (control), decreased the total yield during the two successive seasons. The highest total yield was obtained from compost + microrrhizal on second season 2010 which gave $3.96 \mathrm{~kg} /$ plant.

Role of organics increasing yield of cucumber was attributed to supply of all essential nutrients due to continuous mineralization of organic manures and compost.

Our results also showed that the cucumber responded more to plant compost than the animal manures. This because of the fact that the low $\mathrm{C} / \mathrm{N}$ ratio, phosphorous and EC of the plant compost compared to the other used manures.

Total yield / plant $(\mathbf{k g})$ 
Table 6. Effect of using bio- and organic fertilization on average fruit weight $(\mathrm{g})$ of Queen cucumber cv (Cucumus sativa.) during seasons 2010 and 2011

\begin{tabular}{|ccccc|}
\hline \multirow{2}{*}{ Treatments } & \multicolumn{3}{c|}{ Season 2010 } & \multirow{2}{*}{ Mean } \\
\cline { 2 - 4 } & Phos. & Aoz. & Mr. & \\
\hline Horse manure & $91.6 \mathrm{c}-\mathrm{e}$ & $87.4 \mathrm{c}-\mathrm{e}$ & $94.5 \mathrm{~b}-\mathrm{e}$ & $91.17 \mathrm{C}$ \\
Compost & $105.1 \mathrm{ab}$ & $95.0 \mathrm{~b}-\mathrm{e}$ & $115.0 \mathrm{a}$ & $105.0 \mathrm{~A}$ \\
Chickens manure & $90.8 \mathrm{C}-\mathrm{e}$ & $85.0 \mathrm{de}$ & $96.3 \mathrm{~b}-\mathrm{d}$ & $90.70 \mathrm{C}$ \\
Cows manure & $97.8 \mathrm{be}$ & $91.6 \mathrm{C}-\mathrm{e}$ & $104.5 \mathrm{ab}$ & $97.97 \mathrm{~B}$ \\
\hline Control & $86.7 \mathrm{c}-\mathrm{e}$ & $83.3 \mathrm{e}$ & $88.9 \mathrm{c}-\mathrm{e}$ & $86.30 \mathrm{C}$ \\
\hline Mean & $94.39 \mathrm{~B}$ & $88.47 \mathrm{C}$ & $99.85 \mathrm{~A}$ & \\
\hline \multicolumn{5}{c}{ Season 2011 } \\
\hline Horse manure & $96.30 \mathrm{~b}-\mathrm{e}$ & $85.40 \mathrm{ef}$ & $93.30 \mathrm{c}-\mathrm{e}$ & $91.67 \mathrm{~B}$ \\
Compost & $100.8 \mathrm{be}$ & $93.40 \mathrm{c}-\mathrm{e}$ & $120.3 \mathrm{a}$ & $104.8 \mathrm{~A}$ \\
Chickens manure & $87.53 \mathrm{~d}-\mathrm{f}$ & $91.10 \mathrm{c}-\mathrm{f}$ & $99.40 \mathrm{~b}-\mathrm{d}$ & $92.68 \mathrm{~B}$ \\
Cows manure & $90.50 \mathrm{c}-\mathrm{f}$ & $90.70 \mathrm{c}-\mathrm{f}$ & $107.2 \mathrm{~b}$ & $96.13 \mathrm{~B}$ \\
\hline Control & $80.50 \mathrm{f}$ & $79.40 \mathrm{f}$ & $80.10 \mathrm{f}$ & $80.00 \mathrm{C}$ \\
\hline Mean & $91.13 \mathrm{~B}$ & $88.00 \mathrm{~B}$ & $100.1 \mathrm{~A}$ & \\
\hline
\end{tabular}

Means having the same letter (S) are not significant at $5 \%$ level (Phos) phosphobacterin \& (Aoz) Azotobacter \& (Mr.) mycorrhizal

Table 7. Effect of using bio- and organic fertilization on total yield/plant $(\mathrm{Kg})$ of Queen cucumber cv (Cucumus sativa.) during seasons 2010 and 2011

\begin{tabular}{|ccccc|}
\hline \multirow{2}{*}{ Treatments } & \multicolumn{3}{c|}{ First season } & Mean \\
\cline { 2 - 4 } & Phos. & Aoz. & Mr. & \\
\hline Horse manure & $2.27 \mathrm{c}-\mathrm{e}$ & $1.90 \mathrm{ef}$ & $2.43 \mathrm{~cd}$ & $2.20 \mathrm{C}$ \\
Compost & $3.11 \mathrm{~b}$ & $2.70 \mathrm{be}$ & $3.64 \mathrm{a}$ & $3.15 \mathrm{~A}$ \\
Chickens manure & $2.45 \mathrm{~cd}$ & $2.16 \mathrm{~d}-\mathrm{f}$ & $2.54 \mathrm{~cd}$ & $2.39 \mathrm{C}$ \\
Cows manure & $2.56 \mathrm{~cd}$ & $2.43 \mathrm{~cd}$ & $3.05 \mathrm{~b}$ & $2.69 \mathrm{~B}$ \\
\hline Control & $1.83 \mathrm{ef}$ & $1.73 \mathrm{f}$ & $1.82 \mathrm{ef}$ & $1.80 \mathrm{D}$ \\
\hline Mean & $2.45 \mathrm{~B}$ & $2.20 \mathrm{C}$ & $2.70 \mathrm{~A}$ & $2.45 \mathrm{~B}$ \\
\hline \multicolumn{5}{c}{ Second season } \\
\hline Horse manure & $2.41 \mathrm{~cd}$ & $2.05 \mathrm{ed}$ & $2.35 \mathrm{c}-\mathrm{e}$ & $2.27 \mathrm{ce}$ \\
Compost & $2.89 \mathrm{~b}$ & $2.61 \mathrm{be}$ & $3.96 \mathrm{a}$ & $3.15 \mathrm{~A}$ \\
Chickens manure & $2.71 \mathrm{c}$ & $2.13 \mathrm{dR}$ & $2.67 \mathrm{~cd}$ & $2.50 \mathrm{c}$ \\
Cows manure & $2.26 \mathrm{~d}$ & $2.48 \mathrm{~cd}$ & $3.21 \mathrm{~b}$ & $2.65 \mathrm{~B}$ \\
\hline Control & $1.69 \mathrm{c}$ & $1.62 \mathrm{f}$ & $1.61 \mathrm{ef}$ & $1.64 \mathrm{~d}$ \\
\hline Mean & $2.39 \mathrm{~B}$ & $2.18 \mathrm{c}$ & $2.76 \mathrm{~A}$ & 2.44 \\
\hline
\end{tabular}

Means having the same letter (S) arb not significant at $5 \%$ level (Phos) phosphobacterin \& (Aoz) Azotobacter \& (Mr.) mycorrhizal

These results were in accordance with those of Takeshita et al (1978), Shaheennd El-Habbasha (1988). They found that the growing cucumber under condition of high humidity, moisture and fertilizer had positive effect on total yield of cucumber plants.

\section{Chemical Analysis}

Nitrogen 

Under Plastic Houses

Table 8. Effect of using bio- and organic fertilization on Nitrogen content in fruits (\%) of Queen cucumber cv (Cucumus/ sativa.) during seasons 2010 and 2011

\begin{tabular}{|ccccc|}
\hline \multirow{2}{*}{ Treatments } & \multicolumn{3}{c}{ First season } & Mean \\
\cline { 2 - 4 } & Phos. & Aoz. & Mr. & \\
\hline Horse manure & $2.70 \mathrm{~b}-\mathrm{e}$ & $2.30 \mathrm{~d}-\mathrm{f}$ & $3.07 \mathrm{a}-\mathrm{d}$ & $2.69 \mathrm{~B}$ \\
Compost & $3.40 \mathrm{ab}$ & $2.90 \mathrm{a}-\mathrm{e}$ & $3.30 \mathrm{a}-\mathrm{c}$ & $3.20 \mathrm{~A}$ \\
Chickens manure & $3.10 \mathrm{a}-\mathrm{d}$ & $2.60 \mathrm{~b}-\mathrm{e}$ & $3.20 \mathrm{a}-\mathrm{c}$ & $2.97 \mathrm{AB}$ \\
Cows manure & $3.60 \mathrm{a}$ & $3.00 \mathrm{a}-\mathrm{d}$ & $3.30 \mathrm{a}-\mathrm{c}$ & $3.30 \mathrm{~A}$ \\
\hline Control & $2.10 \mathrm{of}$ & $1.70 \mathrm{f}$ & $2.50 \mathrm{c}-\mathrm{e}$ & $2.10 \mathrm{C}$ \\
\hline Mean & $2.90 \mathrm{~A}$ & $2.50 \mathrm{~B}$ & $3.07 \mathrm{~A}$ & \\
\hline & & Second season & & \\
\hline Horse manure & $2.5 \mathrm{~cd}$ & $2.5 \mathrm{~cd}$ & $3.0 \mathrm{~b}$ & $2.67 \mathrm{~B}$ \\
Compost & $3.6 \mathrm{a}$ & $3.1 \mathrm{~b}$ & $3.5 \mathrm{a}$ & $3.40 \mathrm{~A}$ \\
Chickens manure & $3.0 \mathrm{~b}$ & $2.7 \mathrm{bc}$ & $2.8 \mathrm{bc}$ & $2.83 \mathrm{~B}$ \\
Cows manure & $3.8 \mathrm{a}$ & $3.1 \mathrm{~b}$ & $3.0 \mathrm{~b}$ & $3.30 \mathrm{~A}$ \\
\hline Control & $2.4 \mathrm{~cd}$ & $2.2 \mathrm{~d}$ & $2.7 \mathrm{~cd}$ & $2.33 \mathrm{C}$ \\
\hline Mean & $3.06 \mathrm{~A}$ & $2.72 \mathrm{~A}$ & $2.94 \mathrm{~A}$ & \\
\hline
\end{tabular}

Means having the same letter (S) are not significant at $5 \%$ level (Phos) phosphobacterin \& (Aoz) Azotobacter \& (Mr.) mycorrhizal

Table (7) shows nitrogen content of cucumber fruits as a result of bio-and organic fertilizer treatments.

Adding bio-and organic fertilizers to cucumber plant significantly increased the fruits nitrogen contents as compared to the control in the two successive seasons. The results showed that, with using the cows manure + phosphobacterin (22 $\mathrm{gm} /$ plote). Gaves the highest fruits nitrogen contents during the two seasons, the values was $3.6 \%$ and $3.8 \%$ frome every 100 fruit dry weight respectively.

It can be due either to the effect of cows manure and phosphobecterin on improving soil physical properties, or to a higher mineralization of cows manure which it due to mineral $\mathrm{N}$ in puts. It increased plant availability of macro-and micro nutrients which led to high vegetative growth and more absorption of fruits nitrogen content. The lowest fruits nitrogen content was obtained when plants were grown in control without bio-and organic fertilization.

These results hold good during the two successive seasons. Hunter, (1977) reported that nitrogen nutrition appears to be an important factor affecting fruit quality, but perhaps not in total yield.

\section{Phosphorus}

The average of phosphorus content in cucumber fruits of bio - and organic fertilizers treatments increased by $80 \%$ in cows manure mixed with mycrorrhizal 50\% mixed with Azotobacter and 45\% mixed with phosphorbacterin compared with control treatment for the two successive winters seasons of 2010 and 2011 (Table 9).

The highest $P$ content in fruits was obtained with cows manure $+22(\mathrm{gm}) /$ plotemycorrhizal.

The $\mathrm{P}$ content in fruits decreased by using control only without any organic fertilizers used. The increase of $P$ content on cucumber fruits appeared to be more obvious when the bio-and organic fertilization was mixed and added to the sandy soil which growing cucumber plants.

These results confirmed those obtained by Huang and Lin (2001); Zhang and Fang, (2007) who found that application of organic fertilizers improved the yield of crops, also can correct any deficit of $P$ in the cucumber plants.

\section{Potassium content}

Potassium content on cucumber fruits in the two successive seasons are presented in Table (10). 
Table 9. Effect of using bio- and organic fertilization on Phosphorus content in fruits (\%) of Queen cucumber cv (Cucuimus sativa.) during seasons 2010 and 2011

\begin{tabular}{|ccccc|}
\hline \multirow{2}{*}{ Treatments } & \multicolumn{3}{c}{ First season } & \multirow{2}{*}{ Mean } \\
\cline { 2 - 4 } & Phos. & Aoz. & Mr. & \\
\hline Horse manure & $0.79 \mathrm{bc}$ & $0.67 \mathrm{bc}$ & $0.86 \mathrm{a}-\mathrm{c}$ & $0.77 \mathrm{~B}$ \\
Compost & $0.73 \mathrm{bc}$ & $0.83 \mathrm{a}-\mathrm{c}$ & $0.98 \mathrm{ab}$ & $0.85 \mathrm{AB}$ \\
Chickens manure & $0.80 \mathrm{be}$ & $0.80 \mathrm{bc}$ & $0.80 \mathrm{be}$ & $0.80 \mathrm{AB}$ \\
Cows manure & $0.87 \mathrm{a}-\mathrm{c}$ & $0.91 \mathrm{a}-\mathrm{c}$ & $1.12 \mathrm{a} 0.97 \mathrm{~A}$ & $0.97 \mathrm{~A}$ \\
\hline Control & $0.60 \mathrm{c}$ & $0.64 \mathrm{c}$ & 0.62 & $0.72 \mathrm{~B}$ \\
\hline Mean & $0.76 \mathrm{~B}$ & $0.77 \mathrm{~B}$ & 0.87 & \\
\hline & & Second season & & \\
\hline Horse manure & $0.80 \mathrm{bc}$ & $0.72 \mathrm{~b}-\mathrm{d}$ & $0.91 \mathrm{ab}$ & $0.81 \mathrm{BC}$ \\
Compost & $0.80 \mathrm{be}$ & $0.90 \mathrm{ab}$ & $1.1 \mathrm{a}$ & $0.92 \mathrm{AB}$ \\
Chickens manure & $0.79 \mathrm{~b}-\mathrm{d}$ & $0.75 \mathrm{~b}-\mathrm{d}$ & $0.75 \mathrm{~b}-\mathrm{d}$ & $0.76 \mathrm{C}$ \\
Cows manure & $0.79 \mathrm{~b}-\mathrm{d}$ & $0.96 \mathrm{ab}$ & $1.1 \mathrm{a}$ & $0.95 \mathrm{~A}$ \\
\hline Control & $0.54 \mathrm{~d}$ & $0.59 \mathrm{~cd}$ & $0.61 \mathrm{~cd}$ & $0.58 \mathrm{~d}$ \\
\hline Mean & $0.74 \mathrm{~B}$ & $0.78 \mathrm{~B}$ & $0.89 \mathrm{~A}$ & \\
\hline
\end{tabular}

Means having the same letter (S) are not significant at $5 \%$ level (Phos) phosphobacterin \& (Aoz) Azotobacter \& (Mr.) mycorrhizal

Table 10. Effect of using bio- and organic fertilization on Potassium content in fruits (\%) of Queen cucumber cv (Cucumussativa.) during seasons 2010 and 2011

\begin{tabular}{|ccccc|}
\hline \multirow{2}{*}{ Treatments } & \multicolumn{3}{c}{ First season } & Mean \\
\cline { 2 - 4 } & Phos. & Aoz. & Mr. & \\
\hline Horse manure & $4.9 \mathrm{c}-\mathrm{e}$ & $4.8 \mathrm{c}-\mathrm{e}$ & $5.7 \mathrm{be}$ & $5.13 \mathrm{~B}$ \\
Compost & $5.5 \mathrm{~b}-\mathrm{d}$ & $5.1 \mathrm{c}-\mathrm{e}$ & $6.7 \mathrm{ab}$ & $5.77 \mathrm{AB}$ \\
Chickens manure & $5.0 \mathrm{c}-\mathrm{e}$ & $5.1 \mathrm{c}-\mathrm{e}$ & $6.0 \mathrm{be}$ & $5.37 \mathrm{~B}$ \\
Cows manure & $5.6 \mathrm{bc}$ & $5.4 \mathrm{~cd}$ & $7.2 \mathrm{a}$ & $6.07 \mathrm{~A}$ \\
\hline Control & $4.1 \mathrm{e}$ & $4.0 \mathrm{e}$ & $4.3 \mathrm{de}$ & $4.13 \mathrm{C}$ \\
\hline Mean & $5.02 \mathrm{~B}$ & $4.88 \mathrm{~B}$ & $5.98 \mathrm{~A}$ & \\
\hline & & Second season & & \\
\hline Horse manure & $5.3 \mathrm{ab}$ & $5.0 \mathrm{ab}$ & $6.1 \mathrm{ab}$ & $5.5 \mathrm{AB}$ \\
Compost & $5.7 \mathrm{ab}$ & $5.4 \mathrm{ab}$ & $5.9 \mathrm{ab}$ & $5.7 \mathrm{AB}$ \\
Chickens manure & $5.3 \mathrm{ab}$ & $5.0 \mathrm{ab}$ & $6.3 \mathrm{ab}$ & $5.5 \mathrm{AB}$ \\
Cows manure & $6.0 \mathrm{ab}$ & $5.7 \mathrm{ab}$ & $6.9 \mathrm{a}$ & $6.2 \mathrm{~A}$ \\
\hline Control & $4.7 \mathrm{ab}$ & $4.4 \mathrm{ab}$ & $4.1 \mathrm{~b}$ & $4.4 \mathrm{~B}$ \\
\hline Mean & $5.4 \mathrm{~B}$ & $5.1 \mathrm{C}$ & $5.9 \mathrm{~A}$ & \\
\hline
\end{tabular}

Means having the same letter (S) are not significant at $5 \%$ level (Phos) phosphobacterin \& (Aoz) Azotobacter \& (Mr.) mycorrhizal 


\section{Effect of Using Bio - and Organic Fertilizers on Productivity and Quality of Cucumber Crop 21 Under Plastic Houses}

The average percent of $\mathrm{K}$ content on cucumber fruits of cows manure $+22(\mathrm{gm})$ plotemycorrhizal increased by $68 \%$ and $69 \%$ in two successive winter seasons (2010 and 2011$)$ respectively.

The highest $k$ content on fruits was obtained with cows manure +22 ( $\mathrm{gm} /$ plote) mycorhizalcompared with the other treatments on the first season. The $k$ content on fruits was decreased with control treatment which using chemical mineral only. Using bio-and organic fertilizers increased plant availability of macro and micro nutrients which led to high vegetative growth and more absorption of potassium.

\section{Conclusion}

The use of chemical fertilizers for cucumber plants can lead to nitrate an accumulation and ground water pollution. This study confirmed that the application of bio-and organic fertilizers increased accumulation of organic nitrogen, phosphorous and potassium more than application of minerals fertilizers. Compost and cows manures +mycorrhizal fertilizers were the best management system for increasing soil fertility, cucumber yield and quality and decrease the cost of minerals fertilizers.

\section{REFERENCES}

Abdel-Kawy, T.F.A. 2003. The effect of some organic and in organic fertilizer on plant growth and fruit quality of cucumber plant under plastic house, M.Sc. Thesis faculty of Agric. Ain Shams Univ. Egypt. p. 53.

Abedel-Moniem, E.M.; Abedel-Kawy, T.F.; ElBehairy, U.A. and Abou-Hadid, A.F. 2002. Influence of some organic fertilizers on the yield of cucumber plaints under plastic house, Egyptian Jour. Of hart. 2002. Publ 200429 (3/4) pp. 499-511.

Abou-Hadid, A.F.; Gul, A.; Tuzel, I.H. and Ongun, A.R. 2003. Organic cucumber production under green house conditions. ActaHorti: (608) pp.149-157.

Abou-Hadid, A.F.; Medany, M.; Khalifa, H.; ElBeltagy, A. 1993. Response of growth the development of cucumber and sweet pepper to heating effectiveness Egyptian Journal of Horticulture, 18(2): 185-197.

Arnold, E.; Greenberg, A.P.H.A.; Lenore, G.; Weff, A. and Eaton, W.A. 1992. Standard methods for the exanination of water and waste water p. 115.

Bradly, G.A. and Fleming. J.W. 1958. The effect of nitrogen, phosphorus and potassium applica- tion on the quality of water, J. Am. Soc. Hort. Sci. No. 73 p. 341.

Esawy, M.; Abd El-Kader, N.; Robin, P.; Akkal, N. and Abd El-Rahman, L. 2009. world Journal of Agric Sci., 5(4): 408-414.

Frank, J. 1976. European Greenhouse cucumbers, growing in spring proceedings of the annual, western green house, vegetable growers conference, July 1978. Fresno California USA. No. 9 pp. 43-51.

Hekal, A.I.A. 2001. Evaluation of some cucumber hybrids for resistance to powdery mildew disease under Egyptian environmental conditions. Msc, thesis environ, Sci, Agric., Institute of Environ, studies and Res, Ain Shams Univ., Egypt p. 1.

Huang, S.N. and Lin, J.C. 2001. Current status of organic materials recycling in southern Taiwan. Soil and fertilizer experiment bulletin, 3, pp. 4348.

Hunter, J.C. 1977. Studies on fruit curcature in European green house cucumbers proceeding of the annual, western green house vegetable growers conference. July 1978, fresno. Californa USA. No. 5 pp. 23-29.

Kostov, O.; TZ vetkov, Y.; Kaloianova, N. and van cleemput, O. 1995. cucumber cultivation on some wastes during their aerobic composting. Biore Source Technology, 53(3): 237242.

Maslo, A.V. and Gamayunov A.T. 1989. The effect of prolonged application of fertilizers on the fertility of grey prodcolized soil and the productivity of a vegetable crops. Agrokhimiya No. (1) pp. 73-76.

Miller, R.H. and Keeney, D.R. 1982. Method of soil analysis part (2).

Naseem, M.G. 2003. Methods of soil analysis Book shop mainsheet El-Maarf, Alex., Egypt. p. 200.

Regab, M.A. 1984. Studies on the inheritance of some economic characters in cucumber "cucumissativus L." ph.D. Thesis. Faculty of Agriculture Mansoura University, Mansoura, Egypt.

Roe, N.; Stoffella, P.J. and Graetz, D. 1997. Composts from various municipal solid waste feeds tocks affected vegetable crops 2: Growth, yields and fruit quality. J. Amer. Soc. Hort. Sci., 122: 433-437.

Shaheen, A.M. and El-Habasha, K.M. 1988. Biological and marketable yield often cucumber "cucumissativus L. Ph.D. Thesis. Faculty of 
Agriculture Mansoura University, Mansoura, Egypt.

Takeshita, S.; Kato, M. and Kato, K. 1978. The chemical properties and microflora of the soile associated with the yield of vegetable in a plastic green house. Bulletin of the kanagaua horticultural experiment station No. 25: pp. 69-75.
Vogtmann, H.; Matthies, K.; Kehres, B. and Aeierploeger, A. 1993. Enhanced food quality; Effects of compost on the quality of plant foods. Compost Sci. Util. I: pp. 82-100.

Zhang, M. and Fang, L. 2007. Effect of tillage, fertilizer and green manure cropping on soil quality at an abandoned brick making site. Sail and Tillage Research 93: 87-93. 